\title{
An Assessment of Internal Control Audit on the Efficency of Public Sector in Kogi State Nigeria \\ Onoja E. Emmanuel
}

\author{
Department of Accounting, Kogi , Anyigba \\ Corresponding Author Email:onojaandco@ymail.com, +2348188575556 \\ Michael A. Ajanya \\ Department of Accounting, Salem University, Lokoja \\ Email:ajanyaco@yahoo.com \\ Friday Audu \\ Department of Accounting, Kogi State University, Anyigba \\ E-mail: fridayaudu@yahoo.com
}

Doi:10.5901/mjss.2013.v4n11p717

\begin{abstract}
Internal audit system plays a key role in the assurance chain towards financial accountability. Therefore, the purpose of this study is to provide evidence on the perception about the effectiveness of internal audit accountability in the Nigerian public sector. In other to carry out a proper assessment, the research is centered on the use of auditing to improving public sector management using Kogi State ministry of finance. It also ascertained the extent to which accountability, effectiveness and efficiency of audit mechanism are being promoted in Nigeria. Data were gathered through questionnaires administered to the staff of the state's Auditor-General's office, together with an interview with the Auditor-General of the State on the problems facing the audit and accountability system of the state. Cross tabulations and Chi-square were used to analyze the data. We found out that the internal audit can effectively check fraud and fraudulent activities in the Public Sector and that Public Sectors in Kogi State have significant numbers of Internal Audit Departments to function effectively. It is recommended that Government should provide an adequately equip staff with electronic data processing and also maintains an environment within which internal auditors can have sufficient freedom to accomplish their task efficiently. The study also revealed that the internal control systems in the state are very weak; audit procedures and accountability are as well ineffective due to political interference and skills of some auditing staff. Based on the findings, an effective internal control system free from interference is needed. There is also the need for upgrading the skills of auditing personnel and also strict adherence to statutory and professional standards. Some of these changes require political will at both Federal and State government level
\end{abstract}

Keywords: Accountability, Public Sector, effectiveness internal auditing, management, and fraud prevention

\section{Introduction}

There is general awareness all over the world for the need to pay greater attention to the improvement of public sector management. The reason is obvious, government constitutes the largest single business entity and her pattern of expenditure through its various parastatals, agencies and commissions stimulate lot of economic activities. As a result of these Government huge involvements in economic activities, initiatives are being taken all over the world towards improvement of the standards of accounting and auditing departments in government. The public sector accountant has the responsibility of developing systematic arrangements to assist management in the performance of the services of the institution while the public sector auditor has among other duties, the complementary role to examine whether management actually performs that efficiently. The public sector auditor has to satisfy himself that the account presented have been prepared in accordance with statutory and constitutional requirements and regulation and that proper accounting practice have been observed in their compilation. With the growing size and complexity of public sector in the recent years, the importance of the internal audit has correspondingly increased so that it is today a major factor in establishing the quality of the public sector internal control and its development has made a considerable contribution to 
the improvement of the public sector management.

The Internal audit is an integral part of the finance structure of public organization. A constant complaint in the sector is that internal audit department is too understaffed and under resourced generally to be fully effective. There exist a lot of arrears of work due to inadequate staffing of Internal Audit Departments. There is inadequate knowledge of Electronic Data Processing (EDP) and Computer for efficient auditing of computerized systems. Most of the public sector management working papers do not provide adequate documentation because of this Problem. Staff of the internal audit department is not well remunerated and it makes them to lack interest in their work. Many adduce the argument that internal auditors, being employees in public sector do not have the liberty to exercise the unbiased and independent attitude so necessary to an auditor. In the heat of the controversies for inept public sector performances, Nigeria as a developing economics and Kogi State in particular has to gear her resources for effective developmental utilization and the need for the services of Internal Auditors in the Public Sector becomes more imperative. .

Therefore, the purpose of this research is to assess internal control audit on the accountability of public sector in Kogi State, Nigeria.

In order to achieve the stated objectives, the researchers stipulated the following null hypothesis; effective

Ho1: The internal control system in operation in Kogi state regarding auditing of public sector account is not

Ho2: Auditing of public sector accounts in Kogi state does not enhance effective accountability.

\section{Literature}

Unegbu and Obi (2012) defined internal audit as part of the Internal control system put in place by management of an Organization to ensure adherence to stipulated work procedure and as aid to management. According to Unegbu \& Obi (2012) Internal audit "measures, analyses and evaluates the efficiency and effectiveness of other controls established by management in other to ensure smooth administration, control cost minimization, ensure capacity utilization and maximum benefit derivation. In the view of Adeniji (2011) Internal audit is part of the internal control system put in place by management of an organization. It is an aid to management; it ensures that the financial operations are correctly carried out according to the law and also in accordance with the wishes of the board or council. Internal audit is a branch of management, which enables compliance with established financial instructions on expenditures. In order to achieve agreed objectives, public sector officers must incur expenses in line with established financial instructions. It is the responsibility of the internal audit to ensure adherence to these instructions by personnel involved in public sector administration.

According to Howard (2008) it is appropriate to contrast the public sector with that of private sector. To the former, the main objective of the enterprise in principles is not to make profit but render services. Nwanyawu (2010) opined that public sector auditing means independent examination of and expression of opinion on the financial statements of government establishment, by appointed auditor in pursuance of that appointment and in compliance with the enabling constitution. The final accounts in the public sector especially for the Federal, State and Local government are classified into funds, including:

a. Consolidated Revenue Fund

b. Development Fund

c. Treasury Fund

d. Special and Trust Funds

e. Contingency Fund.

Vos (1997) said that objective of internal auditor is to evaluate effectiveness of financial and operating control, confirm compliance with company policies, procedure, protect assets verify the accuracy and consistency of organization's external and internal reports. Stoner (1994) was of the opinion or view that the objective of internal audit is to evaluate several of the organization's reports for accuracy and usefulness and also recommending improvement of the control system. Owler and Brown (1999) stipulated that the objective of internal auditor is to protect management against errors of principle and neglect of duty. Barker

(1999) agreed with Owler and Brown but added that it is to review the operations and record of the undertaking and in the course of these checks much of the detailed work of the organization in respect of financial and other statements are effectively audited.

Tracey (1994) is of the view that it is the responsibility of the internal auditor to review how well the accounting system works and also evaluate the effectiveness and efficiency of many operations in the organization. A lot of public 
sector has been operating without internal auditor. This can be attributed to the fact that few people outside the accounting profession realize the importance of the internal auditor. Emphasis was laid on discharging accountability for the use of owners fund through the internal auditor report. Some public sector management adduces the argument that internal auditors, being employees in public sector do not have the liberty to exercise the unbiased and independent attitude so necessary to an auditor.

\section{Perspectives of Accountability}

\subsection{The Traditional Perspective}

This is the simplest model, with a coherent chain-from official to official in the bureaucracy, from official to minister, from minister to parliament, from parliament to the people. Under the traditional perspective, each official is technically accountable, through the hierarchical structure of the bureaucracy, to elected politicians and to the citizens. In the ideal traditional view, as under all other perspectives, honesty, integrity, impartiality and objectivity form the code the behavior of officers as they administer rules decided by the politicians.

\subsection{The Democratic Perspective}

This is closely related to the traditional perspective but incorporates the notion of the public being passive consumers of public services and that the traditional channels of accountability have been downgraded in favour of managerial notions. This perspective highlights both representative and participatory forms of democracy as channels for holding public administration to account. These channels may have been downgraded in favour of others by recent reform initiatives; they do however, still exist and have the potential to impact on the activities of public administration.

\subsection{The Professional Perspective}

This is based on what Clarke (2009) described as the view sold to the public that in the 1960s and 1970s that both bureaucracy and professionalism represented transcendent sets of rules and knowledge (expertise) which guaranteed the neutrality of state intervention. However, in the 1980s and 1990s bureaucracy and professionalism have been identified as partisan interests which require the creation of new political disciplines (the market place, management and the evaluative state) to check their powers.

\subsection{The Managerialist Perspective}

Recognizes that accountability operates at two levels-the strategic level for which politicians are responsible and the operational level, which is the sphere of managers (Deakin and Walsh, 1996). The test of legitimacy of public service is the acceptability of the services it produces for the citizen. The shift in modern governments to setting clear objectives, measuring performance and separating policy from administration makes officials as much accountable for the end product (that is, policy outcomes) as politicians. However, Stewart and Stocker (2011), argue that this shift is the ideal, which may not always be achieved in practice.

\subsection{The Governance Perspective}

According to Rhodes (1996) it is difficult to define governance perspective because the term governance has acquired a multitude of different meanings. The governance perspective is, however, closely related to the managerialist frame of reference but moves beyond traditional institutions of government by emphasizing the external dependence and internal fragmentation of the state, which inhibit its capacity to effectively govern.

According to Rhodes (2000), this perspective is more contemporary in recognizing the reality of partnerships and networks of arrangement in today's joined up public sector and the changing scale, character, scope and complexity of public service delivery. According to Pierre and Stoker (2011) the governance perspective thus highlights the apparent tension between new forms of political coordination and steering on the one hand and a powerful legacy of channels and instruments for political accountability on the other. 


\subsection{The Regulatory Perspective}

Emphasize the use of authority, rules and standard setting, particularly displacing an earlier emphasis on public ownership, public subsidies and directly provided services. Consequently, accountability is no longer ensured through line management relations within clear hierarchical structures but through increased surveillance and audit and hands off regulation (Hood, 1999).

\subsection{The Rational Choice Perspective}

This is based on rational choice theory, which explains social phenomena from the beliefs and goal of individuals (Ward, 1995). Thus, the rational choice perspective on accountability emphasizes psychological and behavioral factors in public administrators that result in individuals by highlighting the potential for public administrators to evade traditional, democratic and other channels of accountability. According to this perspective only by focusing on individual political strategies of these actors could a true picture of accountability emerge. Dowding (2010) have however argued that rational choice perspective is not a rival to other perspectives in politics. Rather it is a method of study, which may illuminate other approaches and provide a dynamic explanation of their descriptive and categorical forms. This is more so if it is recognized that accountability goes beyond rendering stewardship. This is so because governing is a very complex process in which assessments are made whether ones use of allocation of resources is better or yields more benefits than another. This complexity has very serious consequence when decisions taken by public officers are brought under open and public scrutiny particularly by those who were either not parties to those decisions or are even incapable of appreciating the intricacies of such decisions.

\section{Principles of Effective Accountability}

The preceding sections discussed the various perspectives of looking at accountability. However, Anonymous (1997 and 2001) contend that there are five principles of effective accountability with each principle referring to an aspect of accountability especially to the newer forms of accountability relationships, such as through alternative service delivery mechanisms. The five principles are as follows:

Roles and responsibilities: The roles and responsibilities of the parties in the accountability relationship should be well understood and agreed upon. Such an understanding provides the context within which both parties will respond and perform. Without this understanding and the required clarification, the basic underpinnings of an effective relationship would be absent.

Performance expectations the objectives being pursued, the accomplishments expected, this is, what each party is expected to contribute to the result, including the inputs and outputs to achieve the desired outcomes and the constraints to be expected should be explicit, understood and agreed upon. Without a clearly spelt out expected outcomes, it would be impossible to determine whether these outcomes have been realized.

The performance expectations need to be clearly linked to and in balance with the capacity, that is, authorities, skills and resources of each party to deliver. The absence of a plausible link between what is expected and the authorities and resources supplied will tend to undermine the effectiveness of accountability. Consequently, expectations that are well beyond what is reasonable for the resources provided will not be believed. Accordingly effective accountability is enhanced by clarity of the links and balance, between resources and expected result.

Able reporting: Effective accountability requires reporting what has been accomplished to bodies to whom the parties are responsible (such as parliament) and to the other parties in the accountability relationship. For the report to be useful, it must be seen as credible and must be timely. It must describe results accomplished, resources and actions taken in light of the agreed expectations. The report must also attribute responsibility in some manner for shortcomings. Depending on the circumstances, reporting can be ongoing, periodic or both. In some situations, external audit can be used to enhance the credibility of performance information.

Reasonable review and adjustment: A credible review and feedback on the performance achieved should be carried out by the accountable parties. Where achievements are below agreed levels, the causes of the under performance are recognized and necessary corrective actions are taken and possible adjustments to the accountability arrangement made and lessons-learned noted. An accountability relationship without follow-ups is clearly incomplete and unlikely to be effective. 


\section{Roles and Responsibilities of Internal Auditor}

Internal auditors owe a responsibility to the management and the board, providing them with information about the adequacy and effectiveness of the sector's system of internal control and the quality of performance.

The internal auditor ensures adherence to all financial, personnel, lending, data processing, the other administrative policy and procedure as well as the economy, efficiency and effectiveness with which resources are used. Internal audit serves a major management control tool are to provide an assurance to management that the financial information furnished to management to aid decision making is reliable, accurate and based on reliable records and where otherwise to draw the attention of management to deficiencies in the organization or system of internal control and to highlight areas of management practices requiring corrective actions.

Other responsibilities are:

To review, evaluate and report on the adequacy or otherwise of financial control framework existing in the agency and its efficiency in assuring property, prudence, completeness and accuracy of the agency's activities and transactions: To carry out a complete and continuous auditing of the accounts and records of revenue, expenditures, plant, stores and other property; To evaluate whether actual performance is within the established financial control framework (compliance auditing). following:

According to Johnson (1996) General duties of an internal auditor in the public sector management include the

a. An audited copy of a statement of the accounts is to be submitted in a prescribed form together with any report to the appropriate minister or secretary of state who in turn presents the accounts before the National Assembly.

b. The auditors must state whether the accounts in their opinion give a true and fair view of the operation affairs.

c. The auditor must state whether the accounts give all the information required under enabling statute.

d. The auditors will normally report if they are not satisfied with any aspects of the $f$

Purposes of Auditing System in A Public Sector Management

There are three major types of report that are basically germane for auditing purposes.

These are for:

1. The internal reporting to managers for purposes of planning and control of current and anticipated operations.

2. The internal reporting to chief Executives and Directors or Managers for institutional policy decisions and the formulation of long range plans.

3. The external reporting mainly for credibility purpose before external entities, government, financial houses, foreign creditors especially for legislation and decision on lending and investment activities.

\section{Control in Public Sector Management}

In the eye of Woolf (1986) the public sector is primarily composed of non-profit making organizations. Management control in its broadest context is the means by which an organization carries out its objectives effectively and efficiently. Public sector management can be generally distinguished as having hierarchical structures composed of responsibility centers, units, sections, departments and divisions. Central government department, the natural health services depend directly on the exchequer for all their funds. If changes are made for certain services they are usually nominal and have a little impact on the level of services offered.

Autonomous bodies are subjected to high degree of Central government control. Local government authorities receive by far the largest proportion of their funds through the rate support grant or allocation. They can equally raise revenue locally, primarily by levying rates; the extent of their power is strictly monitored by central government.

Therefore, the management and control of the public purse is the heart of government administration. The internal audit reports directly to the chief executive, the financial regulations, however, enjoins the chief executive of each ministry to ensure that the accounting and finance functions and internal audit functions are placed under the direct control of suitable competent accountants.

\section{The Ineffectiveness of Internal Auditing and Economic Implications in the Public Sector Management}

The dramatic collapse of the global stock markets and subsequent economic crises with its impacts, which accompanied it, resulted in a sharp concentration in both public and private sector established in Nigeria. For an economic 
development of any public sector to be put correctly as well as guard the pattern its revenue and expenditure, a proper record of the expenditure items must be kept. The effectiveness of auditing System can be reinforced. Economically, internal auditing is meant for internal consumption with varying socio-economic benefits. In Public Sector according to Azubike (2002), internal control is highly effective in increasing the reliability of accounting data and in protecting against fraud. The economic implications of an ineffective auditing system in a public sector management are the negative aspects of the positive development of the auditing system such as:

i. i Inability to plan effectively due to the availability of unconfirmed financial operations of the enterprise in past years.

ii. Inability to make effective financial decision.

iii. Lack of credibility of enterprise before external entities-government financial house, creditors etc.

iv. Inadequacy of information about the enterprise's assets.

v. Inability of the enterprise to rely on any proper statement on past, current and proposed future balance sheet on revenue, revenue sources, expenditure items, profits and losses.

vi. Difficulties in controlling the financial operations of the enterprise.

vii. There is the possibility of the emergence of fraud.

viii. Inability to detect easily the compliance of enterprise financial accounts with the requirement of law.

Aims for ineffectiveness of internal auditing in the Public sector management re as follows.

Lack of Audit Manual: The absence of standard internal audit manual and detailed audit work plan will affect the quality of work particularly for internal auditors who are either non-accountants or nonqualified Accountant.

on-Career Auditors and Lack of Growth Prospect: Most internal auditors who are professionally qualified accountants have been prevented from ascending to levels or status that are equivalent to those held by their professional colleagues in the finance/accounts department. This gives such colleagues in the accounts department an advantage and a feeling of superiority to the internal auditor hence they stifle with imparity the process of information flow to the auditor and makes available only thing they want the auditor to see.

Reporting Structure and Professional Independence: The internal auditor used to be a unit of the accounts department in the past but to ensure a level of independence, they were made to report directly to the Chief Executive. The change however negatively impacted on Public Sectors as most Chief Executives are political officeholders, having no permanent interests and leading to non-commitment to internal audit reports.

Scope of Work: The absence of a proper definition of the duties, rights, privileges and limitations of the internal auditors also inhibits the satisfactory performance of his duties.

Privileges Of Office: The lack of adequate remuneration and pre-requisites of office has made some internal auditors to compromise their positions in favor of fraud stars.

Hazards Of Office: Another factor, which impairs internal audit efficiency, is the hazards that stare the honest and principled internal auditor in the face there are reported cases of assassinations, burglary, native medicine and acid attacks on the lives and properties of internal auditors.

\section{Methodology}

\subsection{Brief on the Population of study:}

Kogi State is located in North-Central Nigeria. Created on August 2Ist 1991.Kogi State borders Nasarawa State and FCT to the North, Benue State to the East, Enugu,Anambra, Edo, Ondo States the South,Ekiti and Kwara States to the West. The capital of Kogi State is Lokoja. The ministry of finance is charged with the responsibility of formulating and implementing the financial, monetary and overall development plan policies of the state Government. It is also responsible for the collection, safekeeping and disbursement of Government funds in such a way that efficiency in the utilization of the financial resources is enhanced just as it collects and analyzes vital statistics for rational decisionmaking. The following parastatals are under the supervision of the ministry:

i. Board of Internal Revenue

ii. State Pension Board 


\section{Data Presentation and Analysis}

\subsection{Effectiveness of Internal Control System}

Information in Table 2 shows that many of the staff of the Auditor General's Department who were interviewed did not think the internal control systems were effective. Approximately one-third of the interviewees believed the internal control systems were effective compared with $38 \%$ who did not consider the internal control systems were effective and $27 \%$ could not tell whether the control systems were effective. This finding may explain why $70 \%$ of interviewees did not perform these control checks.

Table 3 presents information on the mode of confirming the values of stores and stocks in the public sector during the course of an audit. According to this information, just over 50\% the respondents acknowledged that stores and stock are physically counted the during auditing compared to $22 \%$ who contended that stores and stocks are confirmed by observation. Sixteen percent of the respondents were of the opinion that stores and stocks are confirmed by studying the storekeeper's book only.

Table 1: Use of Internal Control Systems

Source: Survey, 2013

\begin{tabular}{|l|c|c|}
\hline \multicolumn{1}{|c|}{ Responses } & No of Respondents & Percentage \\
\hline Often & 21 & 26 \\
\hline Sometimes & 3 & 4 \\
\hline Not at all & 57 & 70 \\
\hline Total & 81 & 100 \\
\hline
\end{tabular}

The remaining $6 \%$ contend that stores and stocks are confirmed by all the three methods stated earlier. Ideally, stores and stock should be physically checked to confirm that they agree with the No.s entered in the bookkeeper's book.

Table 2: Effectiveness of Internal Control Systems

\begin{tabular}{|l|c|c|}
\hline \multicolumn{1}{|c|}{ Responses } & No of Respondents & Percentage \\
\hline Very effective & 23 & 35 \\
\hline Not effective & 36 & 38 \\
\hline Can not assess & 22 & 27 \\
\hline Total & 81 & 100 \\
\hline
\end{tabular}

Source: Survey, 2013

The method of confirming the accuracy of entries is even worse where auditing of salaries and wages is concerned. As shown in Table 4, only 38\% of the respondents were of the opinion that salaries and wages are audited against comprehensive staff lists.

Thirty one percent of respondents believed that auditing of salaries and wages was done using performance evaluation card compared with $25 \%$ who believed it was done by checking the personal emolument cards. Only $5 \%$ of respondents believed that all the above-mentioned methods were used. In a situation where corruption is rife and the possibility of ghost workers cannot be underestimated, the credibility of the auditing system would have been enhanced by using personal enrolment cards which are more effective tan using comprehensive list of employment or staff performance evaluation cards.

Table 5 reports the opinion of respondents regarding whether the auditing process conforms to statutory, professional and ethical standards. While $52 \%$ thought the auditing and accountability procedure in the state public sector was in accordance with statutory professional and ethical standard $48 \%$ believed that this was not the case. The large No. of respondent believing that the system of audit and accountability in the state is not in accordance with statutory professional and ethical standard if true should be a worry. Similar views about were expressed in Table 6 by respondents on the adequacy of audit and accountability process in the State where almost have of the respondents believed that the system of audit and accountability was not satisfactory.

Table 7 presents information on the perception of respondents on the extent to which accountability enhances efficiency in government operations. According to information in the Table 7,63\% of respondents either agreed strongly 
or agreed that accountability enhances good governance.

Table 3: Mode of auditing stores and stocks

Source: Survey, 2013

\begin{tabular}{|l|c|c|}
\hline \multicolumn{1}{|c|}{ Responses } & No of Respondents & Percentage \\
\hline Physical counting & 45 & 56 \\
\hline Observation & 18 & 22 \\
\hline Examining the storekeepers books & 13 & 16 \\
\hline All the above & 5 & 6 \\
\hline Total & 81 & 100 \\
\hline
\end{tabular}

Table 4: Mode of auditing salaries and wages

\begin{tabular}{|l|c|c|}
\hline \multicolumn{1}{|c|}{ Responses } & No of Respondents & Percentage \\
\hline Obtain comprehensive staff list & 31 & 38 \\
\hline Obtain performance evaluation card of each staff & 25 & 31 \\
\hline Check personal emolument card & 20 & 25 \\
\hline All of the above & 5 & 6 \\
\hline Total & 81 & 100 \\
\hline
\end{tabular}

Source: Survey, 2013

Table 5: Adherence to statutory, professional and ethnical standards

\begin{tabular}{|c|c|c|}
\hline Responses & No of Respondents & Percentage \\
\hline Yes & 42 & 52 \\
\hline No & 39 & 48 \\
\hline Total & 81 & 100 \\
\hline
\end{tabular}

Source: Survey, 2013

Table 6: Adequacy of audit and accountability

\begin{tabular}{|c|c|c|}
\hline Responses & No of Respondents & Percentage \\
\hline Yes & 45 & 56 \\
\hline No & 36 & 44 \\
\hline Total & 81 & 100 \\
\hline
\end{tabular}

Source: Survey, 2013

Table 7: Effect of accountability on efficiency in government operation

Source: Survey, 2013

\begin{tabular}{|l|c|c|}
\hline \multicolumn{1}{|c|}{ Responses } & No of Respondents & Percentage \\
\hline Strongly agree & 28 & 35 \\
\hline Agree & 23 & 28 \\
\hline Disagree & 30 & 37 \\
\hline Total & 81 & 100 \\
\hline
\end{tabular}

Table 8: Effect of auditing of public sector on effective accountability

Source: Survey, 2013

\begin{tabular}{|l|l|l|}
\hline Responses & No of Respondents & Percentage \\
\hline Very effective & 31 & 38 \\
\hline Not effective & 55 & 43 \\
\hline Cannot assess & 5 & 9 \\
\hline Total & 81 & 100 \\
\hline
\end{tabular}


The remaining 37\% disagreed that accountability has any impact on the efficiency of government operations.

Table 8 also paints the not-flattering opinion of the respondents about auditing and accountability process in the State, with $38 \%$ of respondents contending that auditing enhances effective accountability while $43 \%$ held the opposite view. The remaining $19 \%$ of respondent could not say whether auditing and accountability of public sector has any effect on effective accountability.

\section{Testing of Hypothesis}

Here, we use Chi-square statistics to test two hypotheses using our survey results. The hypotheses are to establish whether based on the survey results we can conclude that:

- Internal control systems in operation in the state regarding auditing of public sector accounts are effective.

- Whether auditing of public sector accounts in the state enhances accountability.

\subsection{Hypothesis One}

$\mathrm{H}_{0}$ : The internal control system in operation in Kogi state regarding auditing of public sector account is not effective.

$\mathrm{H}_{1}$ : The internal control in operation in the regarding auditing of public sector account is effective.

The chi-square is calculated from information in Table 9:

Computed chi-square 3.448

Chi-square tabulated (\% level of 9.49 significance)

Since the calculated chi-square is less than tabulated chi-square the null hypothesis that internal control systems in auditing public sector accounts are not effective is accepted.

\subsection{Hypothesis Two}

$\mathrm{H}_{0}$ : Auditing of public sector accounts in Kogi State does not enhance effective accountability.

$\mathrm{H}_{1}$ : Auditing of public sector accounts in Kogi State enhances effective accountability.

The chi-square for testing hypothesis 2 is based on information in Table 10.

Computed chi-square 3.9728

Chi-square tabulated (\% level of 9.49 significance)

Since the calculated chi-square is less than tabulated chi-square the null hypothesis that internal control systems in auditing public sector accounts are not effective is accepted.

\section{Conclusion and Recommendations}

The guarantee of complete independence and non-interference in the work of audit department is essential for a quality audit work to be performed as well as effective line of accountability. According to our results the internal control system in the State is not considered to be effective by a sample of the Auditor General's Department.

We also recommend that the internal auditors should ensure that reviews of various departmental functions of There is an inevitable need for today's auditors to acquire the requisite technique and skills in computer operations and electronic data processing because of the impact, which the advent of computer has made in our lives. It is envisaged that some task such as salary preparation, pension accounts, automation of vote book recording and many other could be tapped.

In a system where manpower or manual operation are in use as it is a known fact, auditors are expected to operate at a tolerable level of performance for total system to run properly. Therefore training personnel as well as other training infrastructure becomes an important ingredient in the successful operation of control in such government parastatals, public sector organizations are carried out periodically in order to identify weaknesses in executing responsibilities and make recommendations for improvements such reviews should either be weekly, fortnightly or monthly. Heads of internal audit unit should be in attendance at top management meetings to be aware of policies affecting organizational objectives. 


\section{References}

Adeniyi A.A. (2011): Auditing and Investigations Wyse Associates Limited, Ikeja Nigeria. Pp. 204.

Adesola, S.M., 2001. Public Sector Financial Management and Accounting Comfort. Press and Publishing Co. Ltd., Lagos, pp: 61.

Anonymous, 1974. Udoji commission federal ministry of information. Main Report of the Pub Service Review Commission, Federal Government of Nigeria, Lagos.

Anonymous, 1974. Udoji commission federal ministry of information. Main Report of the Pub Service Review Commission, Federal Government of Nigeria, Lagos.

Anonymous, 1997. Government Accountability, Office of the Auditor General. Alberta Bull. Edmont, pp: 1-15.

Anonymous, 1997. Government Accountability, Office of the Auditor General. Alberta Bull. Edmont, pp: 1-15.

Anonymous, 2001. Auditing for better pubic accountability. Office of the Auditor General of British Columbia, Bulletin Graphic Designer Victoria, pp: 1-7.

Anonymous, 2001. Auditing for better pubic accountability. Office of the Auditor General of British Columbia, Bulletin Graphic Designer Victoria, pp: 1-7.

Clarke, J., 1994. Managing Social Policy. Sage Publishing Co., London.

Clarke, J., 2009. Managing Social Policy. Sage Publishing Co., London.

Day, P. and R. Klein, 1987. Accountabilities Five Public Services. Tavistock Publishing, Basingstoke.

Day, P. and R. Klein, 1987. Accountabilities Five Public Services. Tavistock Publishing, Basingstoke..

Deakin, N. and K. Walsh, 1996. The enabling state the role mark. Contracts Public Administ., 74: 33-48.

Deakin, N. and K. Walsh, 1996. The enabling state the role mark. Contracts Public Administ., 74: 33-48.

Dowdall, J., 2003. Audit and accountability in government. Report of a Joint Seminar Organized by Institute of Governance and Economic and Social Research Council of Northern Ireland, pp: 1-2.

Dowdall, J., 2003. Audit and accountability in government. Report of a Joint Seminar Organized by Institute of Governance and Economic and Social Research Council of Northern Ireland, pp: 1-2.

Dowding, K., 2000. Understanding Urban Governance. MacMillan Publishing, Basingstoke..

Dowding, K., 2010. Understanding Urban Governance. MacMillan Publishing, Basingstoke.

Hood, C., 1999. Regulation Inside Government. Oxford University Press, UK.

Johnson, N., 1974. Defining accountability. Public Administration Bull., 17: 3-13.

Hood, C., 1999. Regulation Inside Government. Oxford University Press, UK.

Johnson, N., 1974. Defining accountability. Public Administration Bull., 17: 3-13.

Pierre, J. and G. Stoker, 2000. Towards Multi Level Governance in Dunleavy. P. Gamb Macmillan, Basingstoke.

Pierre, J. and G. Stoker, 2000. Towards Multi Level Governance in Dunleavy. P. Gamb Macmillan, Basingstoke.

Printer Anonymous, 1999. Constitution of the federal republic of Nigeria, 1999. Federal Government of Nigeria, Lagos Government.

Printer Anonymous, 1999. Constitution of the federal republic of Nigeria, 1999. Federal Government of Nigeria, Lagos Government.

Rhodes, R.A.W., 1996. The New Governance. Governing without government, political studies, 44: 652-667.

Rhodes, R.A.W., 1996. The New Governance. Governing without government, political studies, 44: 652-667.

Rhodes, R.A.W., 2000. The governance narrative key findings and lessons from the ESRC's Whitehall programme. Public Administrat., 78: $345-363$.

Rhodes, R.A.W., 2000. The governance narrative key findings and lessons from the ESRC's Whitehall programme. Public Administrat., 78: $345-363$.

S.M., 2001. Public Sector Financial Management and Accounting Comfort. Press and Publishing Co. Ltd., Lagos, pp: 61.

Stewart, J. and G. Stoker, 2011. Fifteen Years of Local Government Restructuring: An Evaluation. In: Local Government in the 1990, Stewart, J. and G. Stoker (Eds.). Macmillian, Basingstoke, London.

Stewart, J. and G. Stoker, 2011. Fifteen Years of Local Government Restructuring: An Evaluation. In: Local Government in the 1990, Stewart, J. and G. Stoker (Eds.). Macmillian, Basingstoke, London.

Unegbu A.O and Obi B.C. (2012): Auditing Hipuks Additional Press Uwani Enugu. Pp. 7

Ward, H., 1995. Rational Choice Theory. In: Theory and Methods in Political Science, Marsh, D. A. Stoker (Eds.). Macmillan, Basingstoke. 